\title{
Evaluation of Gladiolus (Gladiolus hybridus Hort.) Varieties for Vegetative and Floral Characters under Bundelkhand Conditions
}

\author{
Ajay Kumar Singh ${ }^{1 *}$, Rakesh Kumar ${ }^{1}$, K. S. Tomar' ${ }^{1}$, Hitesh Kumar ${ }^{2}$, \\ Sanjeev Kumar ${ }^{3}$ and Amit Kumar ${ }^{2}$
}

\begin{abstract}
${ }^{I}$ Department of Floriculture and Landscape Architecture, College of Horticulture, ${ }^{2}$ Department of Genetics and Plant Breeding, College of Agriculture, ${ }^{3}$ Department of Silviculture and Agroforestry, College of Forestry, Banda University of Agriculture and Technology, Banda Uttar Pradesh-210001, India
\end{abstract}

*Corresponding author

\section{A B S T R A C T}

\begin{tabular}{|l|}
\hline Ke y w o r d s \\
Evaluation, \\
$\begin{array}{l}\text { Gladiolus, Spike, } \\
\text { Rachis, Floret, Vase } \\
\text { life }\end{array}$ \\
\hline Article Info \\
\hline $\begin{array}{l}\text { Accepted: } \\
\text { 18 April } 2020 \\
\text { Available Online: } \\
\text { 10 May } 2020\end{array}$ \\
\hline
\end{tabular}

\section{Introduction}

Bulbous plants constitute one of the most important groups of plants grown for their floral wealth (Kumar et al., 2011a). Among bulbous crops, gladiolus (Gladiolus grandiflorus Hort.), generally called glad (plural gladioli, gladioluses, glads) occupies a prime position among commercial cut flower
Fourteen varieties of gladiolus (Gladiolus hybridus Hort.) were evaluated for various vegetative and floral paramenters under Bundelkhand conditions of Uttar Pradesh during the years 2017-18 and 2018-19. Minimum days to spike initiation were recorded in variety Jester (90.50 days) and variety White Prosperity took maximum days (108.05 days) for spike initiation. Plant height and spike length was recorded maximum in variety White Prosperity $(124.25 \mathrm{~cm}$ and $110.65 \mathrm{~cm}$ ) however, minimum plant height was recorded in variety Punjab Morning $(84.22 \mathrm{~cm})$, and minimum spike length was observed in variety Red White $(65.07 \mathrm{~cm})$. Maximum duration of flowering was exhibited by variety Willas Pink (18.61 days). However, minimum duration of flowering (13.28 days) was recorded in variety Peter Pears. Number of florets per spike was found maximum in cv. Willas Pink (19.95) and minimum number of florets per spike was found in cv. Red White (10.56). Maximum floret size was recorded by Willas Pink $(9.66 \mathrm{~cm})$ and minimum floret size was recorded in White prosperity $(8.27 \mathrm{~cm})$. Maximum vase life was recorded in cv. Black Star (10.22 days) and minimum in White Prosperity (6.95 days). 
made it attractive for use in as cut flower, making bouquets, indoor decoration and in landscaping as herbaceous borders, bedding plant, in rockeries and pots.

Evaluation is the first important step in any crop improvement programme. It is the basic tool for assessing the genetic variability present in any crop species, which could be exploited for its commercialization. The purpose of evaluation is to ascertain its suitability to climate and soil of that particular area. So a particular crop and its varieties should be evaluated in a particular region before recommending to the farmers for cultivation on commercial level. In Bundelkhand region, no or very little work is done on gladiolus crop. As there is always a demand for novel types having attractive colours, uniform opening of florets, more number of florets per spike and more vase life along with high spike and corm yield. In view of this, a trial was conducted to evaluate the performance of various gladiolus varieties for morphological characters in bundelkhand region.

\section{Materials and Methods}

The present experiment was carried out at Experimental farm of Department of Floriculture and Landscape Architecture,Banda University of Agriculture and Technology, Banda, during 2017-18 and 2018-19.The experiment was laid out in a randomized block design with fourteen varieties as treatments with three replications.

The varieties studied in the experiment were Black Star, Peter Pears, Gold Star, Trader Horn, Pink Rose, White Prosperity, Red White, Novalux, Yellow Gold, Candyman, Willas Pink, Jester, Nathan Red and Punjab Morning. The corms were treated with carbendazim $(0.2 \%)$ before planting in field. The corms were planted in beds at a spacing of $30 \times 20 \mathrm{~cm}$. The recommended dose of fertilizer consisting of $30 \mathrm{~g} \mathrm{~N}, 20 \mathrm{~g} \mathrm{P}_{2} \mathrm{O}_{5}$ and $20 \mathrm{~g} \mathrm{~K}_{2} \mathrm{O}$ per $\mathrm{m}^{2}$ was applied in form of urea, single super phosphate and muriate of Potash, respectively. The $\mathrm{P}$ and $\mathrm{K}$ dose was applied in the beds one week before planting as per the treatment combination. Nitrogen was applied in two equal split doses. The first half dose was applied at 3-leaf stage and second half dose was applied at 6-leaf stage. All the recommended cultural operations i.e., irrigation, hoeing, weeding, spraying and fertilizer application was given in time during the entire crop period for obtaining better quality spikes along with high yield. Observations were recorded in five randomly selected plants in each treatment for various vegetative and floral parameters. The data were recorded for days taken to spike initiation, days taken to flowering, plant height $(\mathrm{cm})$, spike length $(\mathrm{cm})$, rachis length $(\mathrm{cm})$, duration of flowering (days), number of florets open at one time, floret size $(\mathrm{cm})$ and vase life (days). The mean value of the data observed was taken to represent a particular genotype with respect to character.

\section{Results and Discussion}

Analysis of variance revealed significant differences among the genotypes for most of the traits studied (Table 1) indicating presence of wider genetic variability, which can be utilized for genetic improvement of desired horticultural trait(s).

The mean performance of gladiolus cultivars varied considerably for vegetative and flowering parameters (Table 2). The perusal of data presented in revealed that minimum days to spike initiation were recorded in Jester (90.50 days) followed by Black Star (90.67 days), However, cv. White Prosperity took maximum days (108.05 days) for spike initiation followed by Pink Rose (106.17 days). 
Earliest flowering was exhibited by cv. Black Star (105.00 days) followed by Jester (105.83 days) and cv. White Prosperity took maximum days to flowering (119.75 days). Late flowering was recorded in cultivar White Prosperity (119.75 days) followed by Pink Rose (117.67 days).

Variation in days taken to spike initiation and flowering might be due to genetic makeup of the cultivars, which might differ from cultivar to cultivar. It might also depend on food reserves in plant that could be related to growth rate of plants regulating accumulation of the requisite level of carbohydrates for slipping. The results are in conformity with the findings of Kadam et al., 2014 and Chourasia et al., 2015 in gladiolus.

The plant height and spike length $(124.25 \mathrm{~cm}$ and $110.65 \mathrm{~cm}$ ) was recorded maximum in $\mathrm{cv}$. White Prosperity followed by Trader Horn $(113.17 \mathrm{~cm}$ and $95.20 \mathrm{~cm})$ and Willas Pink $(111.18 \mathrm{~cm}$ and $94.48 \mathrm{~cm})$, respectively. Whereas cv. Punjab Morning exhibited minimum plant height and spike length was recorded minimum in cv. Red white $(65.07$ $\mathrm{cm})$. Cultivar Willas Pink exhibited maximum rachis length $(61.51 \mathrm{~cm})$ followed by White Prosperity $(53.38 \mathrm{~cm})$ and Black star $(51.77$ $\mathrm{cm})$ and minimum rachis length $(30.51 \mathrm{~cm})$ was found in cv. Red White followed by cv. Punjab Morning (36.74 cm).

The variation in plant height, spike length and rachis length in different varieties may be due to influence of genetic and environmental factors. As each variety has its own characteristic genetic constitution, which contributes significantly to create variability. Similar observations for plant height, spike length and rachis length also reported by Mushtaq et al., 2018; Singh et al., 2017a and Singh et al., 2017b in gladiolus and Kumar et al., 2011b in snapdragon.
Duration of flowering was recorded maximum in cv. Willas Pink (18.61 days) and it is at par with cvs. Nathan Red (17.00 days), Black Star (16.84 days), Jester (16.78 days), Trader Horn (16.50 days), Yellow Gold (16.28 days),White Prosperity (16.23 days) and Gold Star (16.17 days). However, minimum duration of flowering (13.28 days) was found in cv. Peter Pears. The difference in flowering duration among the varieties might be due to difference in their genetic makeup as well as influence of environment and other management factors. Singh et al., 2018 in gladiolus. Number of florets per spike was found maximum in $\mathrm{cv}$. Willas Pink (19.95) followed by cv. Trader Horn (18.11) and White Prosperity (17.64). However, minimum number of florets per spike was recorded in cv. Red White (10.56) followed by Candyman (14.75). Number of florets differs from cultivar to cultivars, this might be due to hereditary traits of the cultivar of the gladiolus, which is governed by genetic makeup of the plants. Similar results on number of florets per spike have been reported by Rani and Singh (2005) in gladiolus. Maximum floret size was recorded by cv. Willas Pink $(9.66 \mathrm{~cm})$ and minimum floret size was recorded in cv. White prosperity $(8.27 \mathrm{~cm})$. Variation in floret size among the varieties might be due to differences in their genetic constitution. Similar results were also advocated by Pandey et al., 2012; Rani and Singh (2005); Partap and Rao (2006) in gladiolus and Kumari and Misra (2009) in snapdragon.

Cultivar Jester showed maximum number of florets open at one time (7.61) followed by Candyman (7.36). However, minimum number of florets open at one time was found in cv. Black Star (5.28) followed by Nathan Red (5.34). This might be due to variation in genetic constitution among the varieties, which ultimately influences the number of florets opened at one time. 
Table.1 Combined analysis of variance of 10 quantitative traits of fourteen genotypes of gladiolus (pooled data)

\begin{tabular}{|c|c|c|c|c|c|c|c|c|c|c|c|}
\hline \multirow[t]{2}{*}{ Source of variation } & \multirow[t]{2}{*}{$d f$} & \multicolumn{10}{|c|}{ Mean sum of square } \\
\hline & & $\begin{array}{c}\text { Days } \\
\text { taken to } \\
\text { spike } \\
\text { initiation }\end{array}$ & $\begin{array}{c}\text { Days } \\
\text { taken to } \\
\text { flowering }\end{array}$ & $\begin{array}{c}\text { Plant } \\
\text { height } \\
\text { (cm) }\end{array}$ & $\begin{array}{c}\text { Spike } \\
\text { length } \\
(\mathrm{cm})\end{array}$ & $\begin{array}{c}\text { Rachis } \\
\text { length } \\
\text { (cm) }\end{array}$ & $\begin{array}{c}\text { Duration } \\
\text { of } \\
\text { flowering }\end{array}$ & $\begin{array}{c}\text { No. of } \\
\text { florets } \\
\text { per } \\
\text { spike }\end{array}$ & $\begin{array}{c}\text { Floret } \\
\text { size } \\
(\mathbf{c m})\end{array}$ & $\begin{array}{c}\text { No. of } \\
\text { florets } \\
\text { open at } \\
\text { one time }\end{array}$ & $\begin{array}{c}\text { Vase } \\
\text { life } \\
\text { (days) }\end{array}$ \\
\hline Replication(Within En) & 4 & 44.67 & 17.26 & 99.81 & 126.80 & 81.73 & $7.21 *$ & 4.98 & 0.87 & 0.78 & 0.46 \\
\hline Year & 1 & 13.31 & 0.06 & 0.19 & 4.38 & 76.50 & 0.90 & 5.34 & 0.00 & 0.44 & 0.64 \\
\hline Genotypes & 13 & $187.91 * * *$ & $148.69 * * *$ & $806.92 * * *$ & $985.72 * * *$ & $368.77 * * *$ & $14.90 * * *$ & $27.39 * * *$ & $1.69 * * *$ & $2.84 * * *$ & $7.59 * * *$ \\
\hline Genotypes x year & 13 & 8.75 & 8.96 & 19.17 & 27.96 & 15.56 & 0.93 & 0.80 & 0.12 & 0.44 & 1.00 \\
\hline Pooled Error & 52 & 23.04 & 12.74 & 107.64 & 103.34 & 34.64 & 2.81 & 2.75 & 0.37 & 0.68 & 0.93 \\
\hline
\end{tabular}

* Indicates significance at $\mathrm{P}=.05 ., * *$ Indicates significance at $\mathrm{P}=.01 ., * * *$ Indicates significance at $\mathrm{P}=.001$

Table.2 Mean performances of 14 gladiolus genotypes for different morphological characters (pooled data)

\begin{tabular}{|c|c|c|c|c|c|c|c|c|c|c|c|}
\hline $\begin{array}{l}\text { Sr. } \\
\text { No. }\end{array}$ & Genotype & $\begin{array}{c}\text { Days taken } \\
\text { to spike } \\
\text { initiation }\end{array}$ & $\begin{array}{c}\text { Days } \\
\text { taken to } \\
\text { flowering }\end{array}$ & $\begin{array}{c}\text { Plant } \\
\text { height } \\
\text { (cm) }\end{array}$ & $\begin{array}{c}\text { Spike } \\
\text { length } \\
\text { (cm) }\end{array}$ & $\begin{array}{c}\text { Rachis } \\
\text { length } \\
\text { (cm) }\end{array}$ & $\begin{array}{c}\text { Duration } \\
\text { of } \\
\text { flowering }\end{array}$ & $\begin{array}{c}\text { No. of } \\
\text { florets per } \\
\text { spike }\end{array}$ & $\begin{array}{c}\text { Floret } \\
\text { size }(\mathbf{c m})\end{array}$ & $\begin{array}{l}\text { No of florets } \\
\text { open at one } \\
\text { time }\end{array}$ & $\begin{array}{c}\text { Vase life } \\
\text { (days) }\end{array}$ \\
\hline 1. & Black Star & 90.67 & 105.00 & 102.02 & 80.10 & 51.77 & 16.84 & 17.06 & 9.09 & 5.28 & 10.22 \\
\hline 2 & Peter Pears & 95.22 & 110.39 & 95.23 & 72.77 & 40.15 & 13.28 & 14.78 & 8.28 & 6.17 & 9.89 \\
\hline 3. & Gold Star & 95.61 & 109.28 & 90.63 & 75.15 & 40.32 & 16.17 & 16.34 & 8.36 & 6.50 & 10.05 \\
\hline 4. & Trader Horn & 93.17 & 106.34 & 113.17 & 95.20 & 50.92 & 16.50 & 18.11 & 9.43 & 5.61 & 8.89 \\
\hline 5. & Pink Rose & 106.17 & 117.67 & 95.44 & 80.14 & 47.15 & 15.89 & 17.14 & 8.31 & 6.51 & 8.11 \\
\hline 6. & White Prosperity & 108.05 & 119.75 & 124.25 & 110.65 & 53.38 & 16.23 & 17.64 & 8.27 & 6.17 & 6.95 \\
\hline 7. & Red White & 92.84 & 107.23 & 85.65 & 65.07 & 30.51 & 13.56 & 10.56 & 8.95 & 5.61 & 10.06 \\
\hline 8. & Novalux & 94.27 & 107.61 & 90.70 & 73.01 & 39.67 & 14.62 & 15.56 & 9.09 & 6.45 & 7.11 \\
\hline 9. & Yellow Gold & 93.56 & 107.17 & 97.46 & 74.75 & 42.07 & 16.28 & 16.95 & 9.13 & 6.61 & 9.89 \\
\hline 10. & Candyman & 95.22 & 106.22 & 89.15 & 70.48 & 43.81 & 13.61 & 14.75 & 9.50 & 7.36 & 8.33 \\
\hline 11. & Willas Pink & 103.86 & 116.69 & 111.18 & 94.48 & 61.51 & 18.61 & 19.95 & 9.66 & 6.56 & 8.22 \\
\hline 12. & Jester & 90.50 & 105.83 & 103.70 & 81.94 & 46.61 & 16.78 & 16.39 & 9.51 & 7.61 & 9.39 \\
\hline 13. & Nathan Red & 95.50 & 108.39 & 107.35 & 89.97 & 47.51 & 17.00 & 17.34 & 9.41 & 5.34 & 8.28 \\
\hline 14. & Punjab Morning & 92.84 & 106.17 & 84.22 & 66.08 & 36.74 & 14.22 & 16.45 & 8.35 & 6.61 & 9.94 \\
\hline & C.D. at $5 \%$ & 7.23 & 5.29 & 16.17 & 15.69 & 9.16 & 2.67 & 2.39 & 0.94 & 1.17 & 1.23 \\
\hline
\end{tabular}


Table.3 Pairwise mean comparison of important traits of the 14 genotypes of gladiolus (pooled data)

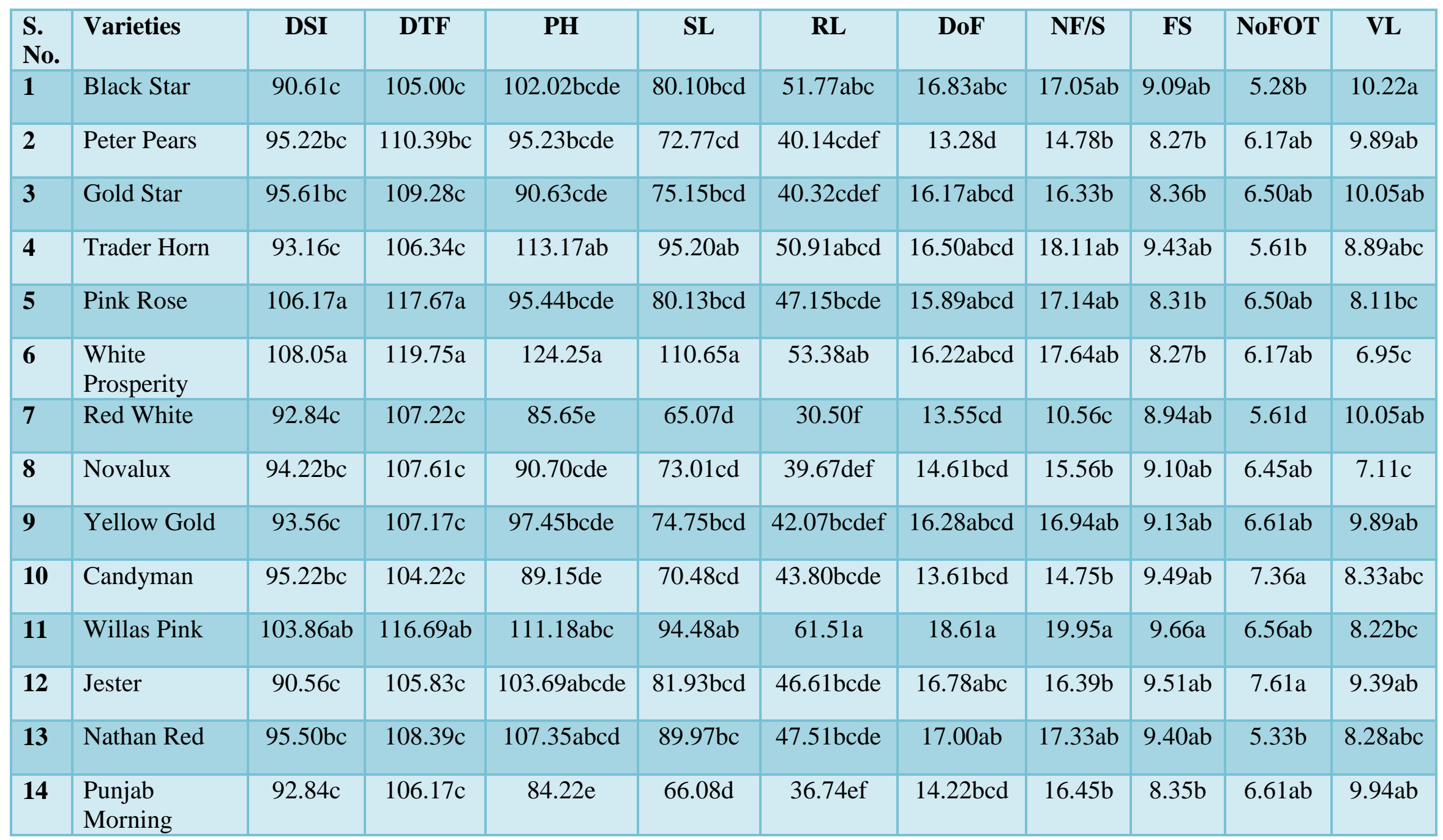

$\mathrm{DSI}=$ Days taken to spike initiation; DTF = Days taken to flowering; $\mathrm{PH}=$ Plant height; SL= Spike length; RL=Rachis length; DoF = Duration of flowering; $\mathrm{NF} / \mathrm{S}=$ Number of florets per spike; FS = Floret size, NoFOT: Number of florets open at one time, VL=Vase life. 




Fig.1 Box plots depicting variations for a) Days taken to spike initiation b) Days taken to 50\% flowering, c) Plant height, d) Spike length e) Rachis Length f) Duration of flowering g) Number of florets per spike h) Floret size i) Number of florets open at one-time j) Vase life 
The results are in conformity with the findings of Singh et al., 2018 in gladiolus. Vase life studies indicated that cv. Black Star recorded maximum vase life (10.22 days) followed by Red White (10.06 days), whereas minimum vase life was recorded in White Prosperity (6.95 days) followed by Novalux (7.11 days).

The variation in vase life might be due to senescing behaviour by producing higher amount of ACC, ethylene forming enzyme and ethylene along with genetic makeup of different genotypes. It might also be due to carbohydrates reserves of flowers, osmotic concentration and pressure potential of petal cells which is influenced by genetic constitution. Vascular blockage might be regarded as the major cause for wilting leading to reduction in longevity of cut flowers.

The findings are in line with the results obtained by Jauhari and Singh (2006) in snapdragon and Laxmi et al., (2008) in chrysanthemum. The pair wise mean comparison and basic descriptive statistics parameters of all traits of the experiment are presented in Table 3.

All genotypes are grouped for each trait using pairwise mean comparison analysis. The genotypes confirm distinct grouping pattern for each trait, where genotype with unique single letter are significantly different from another genotype and means with the same letter are not significantly different. The box plots depicting variability for all the traits are shown in Fig. 1.

Varieties White Prosperity, Traders Horn and Willas Pink exhibited better plant height and spike length and rachis length. Willas Pink also recorded maximum flowering duration, number of florets per spike and floret size. So, on the basis of above findings, these varieties can be recommended for cut flower purpose to the farmers in this region.

\section{References}

Bhattacharjee, S. and L. C. De. 2005. Postharvest technology of flowers and ornamental plants. Aavishkar Publishers, Jaipur, India, 11-19.

Chourasia, A., Viradia, R.R., Ansar, H. and Madle, S.N. (2015). Evaluation of different gladiolus cultivars for growth, flowering, spike yield and corm yield under Saurashtra region of Gujarat. The Bioscan, 10(1): 131-134.

Jauhari, S. and Singh, A.K. 2006. Evaluation of inbred and their $F_{1}$ 's for flowering and postharvest attributes in snapdragon (Antirrhinum majus L.).Journal of Ornamental Horticulture, 9 (2): 91-96.

Kadam, G.B., Kumar, G., Saha, T.N., Tiwari, A.K. and Kumar, R. (2014). Varietal evaluation and genetic variability studies on gladiolus. Indian Journal of Horticulture, 71(3): 379-384.

Kumar, R., Kumar, R. and Kumar, P. 2011a. Effect of integrated use of chemical fertilizers, biofertilizers and biostimulants in gladiolus (Gladiolus grandiflorus L.) cv. Sancerre. Progressive Horticulture, 43(1):149152.

Kumar, R., Kumar, S., Kumar, P. and Mer, R. 2011b. Comparative performance of snapdragon (Antirrhinum majus L.) genotypes under tarai conditions of Uttarakhand. Journal of Scientific and Applied Research. 2(2) :142-147.

Kumari, J. and Misra, K.K. 2009. Morphological characterization and evaluation of snapdragon genotypes for cut flower and seed production purpose under Tarai conditions of Uttarakhand. Journal of Ornamental Horticulture, 12(1): 62-67.

Laxmi, P., Pratap, M. and Reddy, S.A. 2008. 
Evaluation of yellow coloured chrysanthemum (Dendranthema grandiflora L.) cultivars for growth, flowering and yield. Orrisa Journal of Horticulture, 36 (1): 116-119.

Mushtaq, S., Hafiz, I.A., Arif, M. and Anwar, A. (2018). Performance evaluation of elite gladiolus cultivars under agro climatic conditions of Rawalpindi. Asian Journal of Advances in Agricultural Research, 5(3): 1-6.

Pandey, R.K., Bhat, D.J.I., Dogra, S., Singh, A., Laishram, N. and Jamwal, S. (2012). Evaluation of gladiolus cultivars under subtropical conditions of Jammu. International Journal of Agriculture Sciences, 8(2): 518-522.

Pratap, M and Rao, A.M. 2006. Assessment and variability studies in gladiolus. Journal of Ornamental Horticulture, 9 (2): 145-147.

Rani, R. and Singh, C. (2005). Evaluation of different gladiolus cultivars for quality flower production. Journal of Researches Birsa Agriculture University. 17(2): 227-230.

Singh, A. K., Sisodia, A., Sisodia, V. and Ray, P. (2017a). Performance of Indian and exotic varieties of gladiolus under Eastern UP conditions. Journal of Ornamental Horticulture, 20(3\&4): 153-157.

Singh, A.K., Kumar, D., Sisodia, A. and Padhi, M. 2018. Varietal Evaluation of Gladiolus for Flowering Attributes Under Indo-Gangetic Plains. International Journal of Current Microbiology and Applied Sciences, 7(07): 3728-3735.

Singh, D., Mishra, A.,Singh, J. and Meena, B. (2017b) Evaluation of Morphological Characters of Gladiolus (Gladiolus hybridus Hort.) Genotypes under Sub Humid Condition of Rajasthan. International Journal of Agriculture Sciences, 9(7): 3846-3848.

\section{How to cite this article:}

Ajay Kumar Singh, Rakesh Kumar, K. S. Tomar, Hitesh Kumar, Sanjeev Kumar and Amit Kumar. 2020. Evaluation of Gladiolus (Gladiolus hybridus Hort.) Varieties for Vegetative and Floral Characters under Bundelkhand Conditions. Int.J.Curr.Microbiol.App.Sci. 9(05): 26122619. doi: https://doi.org/10.20546/ijcmas.2020.905.299 